\title{
PAIKKOIHIN VIITTAAVAT ILMAUKSET MURTEIDEN JÄLJITTELYSSÄ
}

Aila Mielikäinen

Jyväskylän yliopisto

Lähivertailuja 17.

Toimittaneet Annekatrin Kaivapalu, Külvi Pruuli. Jyväskylä Studies in Humanities, 53.

Jyväskylä: Jyväskylän yliopisto, 2006, pp. 193-215. ISBN 951-39-2450-5

ISSN 1459-4323 


\section{Taustaa}

Naapureihin kohdistuvat ennakkoluulot ja asenteet on ilmaistu aikojen kuluessa monin kielellisin tavoin. Erilaisilla kölleillä (kölli 'liikanimi, haukkumanimi') on nimitelty naapuripitäjien asukkaita tai kauempanakin asuvia, ja murteista on tehty kaskuja ja matkimuksia. Sekä nimittelyissä että murteen jäljittelyissä tulee esiin useampikin asenteelle määritelty funktio: ympäristön hahmottaminen, minäkuvan ja identiteetin rakentaminen ja itsepuolustus (Deprez \& Persoons 1987: 128-130). Mitä läheisemmistä naapureista on kyse, sitä suurempi on itsepuolustusta vaativa "uhka", kun taas kaukaisempiin yhteisöihin suhtaudutaan neutraalimmin (esim. Andersson 2001: 141-143.)

Murrematkimukset ovat ns. kiusoittelusananparsia, joissa jäljitellään jotain murretta, tavallisesti jotain omasta kielenkäytöstä poikkeavaa murrepiirrettä. Esimerkiksi matkimuksessa Mies istuu riessä, nenä riässä, suuret rukkaest kiässä 'Mies istuu reessä, nenä räässä, suuret rukkaset kädessä' on jäljittelyn kohteena savolaismurteiden etelälaidalla esiintyvä myöhäsyntyisen ää:n ja ee:n diftongiutuminen (Kettunen 1930: 128). Tällaisia kieltä karrikoivia ilmauksia on nimitetty kansanrunoudentutkimuksessa myös Vanhasta testamentista tulevalla nimityksellä šibbolet (esim. Kuusi 1954: 112). Sana on kuitenkin alun perin ollut tunnussana, jolla on testattu suhu-s:n ääntämystä. Pirkko Leino, joka on tutkinut murteiden jäljittelyjä, on suomentanut termin matkimukseksi (1968: 1). Matkimukset ovat muiden sananparsien tapaan vakiintuneet tiettyyn muottiin; ne voivat olla pitempiä lauseita, repliikkejä ja wellerismejä, irrallisia fraaseja, sanaluetteloita, köllinimiä ja jopa lauluja. Niitä tunnetaan Suomessa jo 1700luvulta, mutta erityisesti niitä on saatu talteen 1800-luvun jälkipuoliskolta alkaen. Matkimukset on kohdistettu yleensä lähimpiin naapureihin. Toisinaan niissä on mukana useampia murrepiirteitä, ja kielen lisäksi saatetaan pilkata jotain kielenkäyttäjän ominaisuutta, vaikkapa saituutta. (Leino 1968: 1-3.)

Vaikka murteet ovat tasoittuneet ja yhteiskunnalliset ja sosiaaliset olot muuttuneet huomattavasti 1800-luvun tilanteesta, muiden erilaista puhetapaa jäljitellään yhä. Myös murre-erot ovat säilyneet siinä määrin, että niitä pystytään erottamaan, tunnistamaan ja jäljittelemään. Jäljittelyjen muoto poikkeaa kuitenkin monessa suhteessa aiemmista matkimuksista. Läheskään kaikki 
jäljittelyt eivät täytä vakiintuneisuuden kriteeriä, eli ne eivät säily ja leviä enää samassa muodossa. Tällaisiakin matkimuksia on, mutta enimmäkseen jäljittely on tilannekohtaisesti tuotettua tai pienessä piirissä tunnettua. Pitempien repliikkien ja toteamusten sijasta matkitaan enimmäkseen irrallisia sanoja ja sananmuotoja sekä fraaseja. (Ks. Mielikäinen 2005.) Nykyaikaisen kansanlingvistiikan termein murteiden jäljittelyssä on kyse murteen hallinnasta. Dennis Prestonin mukaan (1996: 40-41) hallinta (engl. control) on yksi murretietoisuuden dimensio tai ilmenemismuoto (engl. mode), muita ovat "saatavuus" (availability), paikkansapitäryys (accuracy) ja yksityiskohtaisuus (detail). Hallinta tarkoittaa sitä, että ei-lingvisti pystyy tuottamaan murteen äänne- ja muotoasuja tai pitempiä murteellisia ilmauksia. Saatavuus merkitsee puheenaiheen helppoutta; ei-kielitieteilijä pystyy puhumaan joistakin murreilmiöistä, mutta ei välttämättä kaikista. Edelleen hänen havaintonsa voivat olla oikeita tai virheellisiä ja yksityiskohtaisia tai ylimalkaisia.

\section{Tutkimuskohde ja aineisto}

Tässä artikkelissa tarkastelen paikkaan viittaavien ilmausten käyttöä murrematkimuksissa. Otan huomioon kaikenlaiset murteen jäljittelyt, sekä vakiintuneet että tilapäiset. Käytännön syistä nimitän myös uusia, vakiintumattomia jäljittelyjä matkimuksiksi (toisin Leino 1968: 2). Tärkeintä on, että niissä jäljitellään jotain murretta lauseella, fraasilla, sanaluettelolla tai irrallisella sanalla. Joskus erotan vanhat matkimukset uudemmista nimittämällä niitä sananparsimatkimuksiksi, koska suurin osa niistä on samalla suomalaista sananparsiperinnettä. Paikkaan viittaavilla ilmauksilla tarkoitan paikannimiä (Savo, Laukaa) sekä niistä muodostettuja asukkaiden ja murteiden nimityksiä (laukaalainen, savo 'savon murre'). Käytän näistä kaikista myös yhteistä termiä paikanilmaus.

Suomalaiset sananparret ovat vanhastaan olleet murreasuisia, ja myös sananparsikokoelmiin ne on koottu usein tässä muodossa. Ne sisältävät runsaasti paikkaan viittaavia ilmauksia, kuten esimerkiksi Jäi kun Jämpsän äijä taivaasta (Juupajoki); Aevan varmoo kun leppävirtalaesiin aatuvaaks tulo (Riistavesi; Nirvi \& Hakulinen 2004: 381, 384). Mikä tahansa murteellinen sananparsi ei ole kuitenkaan matkimus, vaan ehtona on, että siinä jäljitellään selvästi murretta. Jäljittelyn kohteena on yleensä vieras murre, mutta myös oman murteen matkiminen on sananparsiperinteessä tuttua (Leino 1968: 37, 79, 148). Joskus on vaikea erottaa matkimuksia muista sananparsista, siis päätellä, onko kiusoittelun tai pilkan kohteena murre vai jokin muu ilmiö. Wellerismit Hei hevoosta! sano hämäläänen härkää (Kauhajoki) ja Mikä toi o? sano isonkarilainen [Isokari Kustavissa] ko ihmise näk (Taivassalo) ovat molemmat puhujan omaa murretta, ja pilkka kohdistuu niissä muuhun kuin kieleen. Wellerismeissä Voi ainiaasa! sanoo laihialaanen kun voinpala leivältä katos (Laihia) ja Turkit, sanoi laokoalainev vaekkei niit oes $k u$ yks (Konginkangas) on huomion kohteena kieli, edellisessä erikoinen huudahduspartikkeli, jälkimmäisessä tutun sanan monikollinen 
käyttö. Soinista merkitty huudahdus Puukoot pystyhyn, Kauhava näkyy! on jo mitä tyypillisin murrematkimus, vaikka siinä viitataan myös puukkojunkkareihin ja tappelemiseen: $i$-diftongin oikeneminen (puukoit $>$ puukoot) ja vokaalienvälisen $h: n$ säilymä ovat eteläpohjalaisia murrepiirteitä eikä niitä tunneta Keuruun-Ähtärin-Evijärven savolaisissa siirtymämurteissa, joihin Soini kuuluu (ks. Kettunen 1940: 107, 201). (Esimerkit teoksesta Nirvi \& Hakulinen 2004: 347, 372, 376, 379.)

Tarkoitukseni on analysoida paikanilmausten käyttöä eri-ikäisissä ja erityyppisissä matkimuksissa. Aineiston olen kerännyt mm. kasku- ja sananparsikokoelmista (Punttila 1998 ja 2001, Nirvi \& Hakulinen 2004), murreasenteita käsittelevistä opinnäytteistä ja muista tutkimuksista (Leino 1968; Leipälä 2000; Arve 2002; Björckbacka 2002; Palander 2005) sekä nykypuhekielen arkistokokoelmista (NPM 1979) ja asennekyselyistä (JY 2004). Ei-kielitieteilijöiden käsityksiä murteista ja murreasenteita on selvitetty viime vuosina mm. lomakekyselyjen (Arve; Björckbacka; Palander), karttatehtävien (Palander) ja nauhoitettujen haastattelujen (Leipälä) avulla. Leipälän ja Björckbackan tutkimukset on tehty Keski-Pohjanmaalla, Arven informantteina ovat olleet Jyväskylän yliopiston opiskelijat, jotka ovat kotoisin tasaisesti eri puolilta Suomea. Oma kyselyaineistoni (JY 2004, ks. myös Mielikäinen 2005) koostuu opiskelijoiden toisille opiskelijoille tekemistä haastatteluista, joissa kysyttiin nimeltä mainittujen murteiden tärkeintä piirrettä. Vastaus oli kirjoitettava siinä muodossa kuin informantti sen sanoi. Murrepiirteiden sijasta tai lisäksi monet kuvailivat kysyttyä murretta omin sanoin, mutta tässä artikkelissa otan huomioon vain selvät jäljittelyt.

Vanhemmassa aineistossani toistuvat usein samat sananparsimatkimukset, ja joissakin kokoelmissa (Nirvi \& Hakulinen 2004) on merkitty muistiin myös paikkakunta. Kaikista käyttämistäni aineistoista paikkakunta ei käy ilmi, joten jätän sen mainitsematta. Sen sijaan uudempien kysely- ja haastatteluaineistojen esimerkeissä viittaan myös informantin kotipaikkaan, ikään ja sukupuoleen. Litteroitujen haastattelujen ja kyselyaineistojen kirjoitusasua olen joskus varovasti korjannut esimerkiksi alkukirjainten merkinnässä (stadi $\rightarrow$ Stadi 'Helsinki') tai sanojen yhteen ja erilleen kirjoittamisessa (ookkonää $\rightarrow$ ookko $n \ddot{a} a ̈$ = oletko sinä), en kuitenkaan itse äänne- ja muotoasuissa. Samoin olen kirjaintanut puolikarkealla transkriptiolla merkityt esimerkit normaalin oikeinkirjoituksen mukaan. Esimerkistön esittelen alueellisessa järjestyksessä länsimurteista itämurteisiin, lounaismurteista hämäläis-, pohjalais- ja peräpohjalaismurteisiin ja savolaismurteista kaakkoismurteisiin.

Vertailen paikallisuuden osoittamista ennen ja nyt ja pohdin tässä valossa erityisesti nimien funktioita, matkimusten muuttumista ja muutosten syitä. Esittelen ensin paikanilmausten tyypit. Sen jälkeen tarkastelen, miten näitä ilmauksia käytetään murretta jäljiteltäessä. Poimin aineistosta muutamia päätyyppejä, joihin paikanilmaukset näyttävät keskittyvän. Murrematkimuksissa on sananparsien tapaan havaittavissa tietyntyyppisiä formuloita, siis sanontoja, joissa on samanlainen muoto, muotti, mutta joiden sisältöä voidaan vaihdella (ks. esim. Kuusi 1954: 140-141). Metakielen näkökulmasta näissä formuloissa ei olennaisinta ole matkimustyyppi, vaan se, miten suorasti tai epäsuorasti 
kielenkäyttäjä tai kieli eksplikoidaan. Ryhmittelyyni vaikuttaa jossain määrin myös se, kohdistuuko matkimus kielenkäyttäjiin vai kieleen. Joissakin tapauksissa puhutaan suoraan tietyn paikkakunnan murteesta tai murrepiirteestä, toisissa murre on tuotu esiin paikannimen äänne- ja muotoasussa, ja joskus nimi on vain taustalla oleva viite. Jäsentely perustuu siis analyysiin, jonka olen tehnyt paikanilmauksia sisältävistä matkimuksista, ja siinä yhdistyy useampi näkökulma aiheeseen.

\section{Paikkaan viittaavat ilmaukset}

Murrematkimukset kohdistuvat vanhastaan yhden pitäjän murteeseen, ja harvemmin on jäljitelty pitäjää pienempien (kylien) tai suurempien alueiden (maakuntien) murteita (Leino 1968: 193-194). Koska paikallisuus on olennainen ilmiö matkimuksissa, on odotuksenmukaista, että niissä myös mainitaan paikannimiä tai muita näihin perustuvia nimityksiä. Toisaalta sosiaalinen ja tilannekonteksti on ollut usein sellainen, että pilkan kohde on tiedetty ilmankin. Matkitun murteenkäyttäjän alueellinen tausta on siis ollut implisiittisesti läsnä itse murteessa ilman että sitä on erikseen mainittu.

Monissa vanhoissa ja nykyisissä matkimuksissa eksplikoidaan silti jokin paikka. Useimmin mainitaan pitäjä, siis kunta, tai kaupunki. Pitäjä on ollut ennen kunnallishallinnon syntyä 1860-luvulla vanha kunnan ja seurakunnan nimitys, ja se on myös pienin alueellinen murteentutkimuksen yksikkö. Vanhoissa murrematkimuksissa on kyse enimmäkseen maaseutupitäjistä, joskus niiden osista, siis kylistä, ja joskus myös kaupungeista: Tyroää, Kitee; Polso (kylä Vetelissä); Turku. Nykyään kaupunkeja käytetään murrealueiden nimeämisessä erityisesti silloin, kun alueella ei ole selvää maakuntaidentiteettiä tai maakuntaan tai heimoon viittaavaa nimeä. Tyypillisiä esimerkkejä alueensa keskuspaikoista ovat Turku, Tampere ja Oulu, ja murteestaan ovat tulleet tunnetuiksi myös Rauma ja Pori. (Leipälä 2000: 18-19; Arve 2002: 58; Mielikäinen \& Palander 2002: 93-95; Palander 2005: 62, 85.) Joskus matkimus kohdistuu laajempaan alueeseen, maakuntaan. Analysoimassani aineistossa mainitaan näistä tosin vain Savo ja Savonmaa, Pohjanmaa ja Lappi, mutta asennetutkimusten mukaan suomalaiset tuntevat muitakin maakuntien mukaan nimettyjä murrealueita.

Jäljittelyssä voidaan viitata myös pitäjän, kaupungin tai maakunnan asukkaisiin. Huomio on tällöin kielenkäyttäjissä, murteenpuhujissa. Heidät mainitaan joko yhteisönä tai yhteisön edustajina. Muodoltaan ilmaus on usein paikannimestä muodostettu lAinen-johdos, kuten perniöläinen, somerolainen, ähtäriläinen ja raumalainen. Johdoksiin kuuluu myös heimojen nimityksiä, kuten hämäläinen ja savolainen, ja näissä tapauksissa on mahdollista mainita vielä puhujan sukupuoli: pohjalaiseukko, savolaispoika. Toinen yleinen asukkaisiin viittaava tyyppi on $X: n$ tyttö $~ X: n$ poika, jossa genetiiviattribuuttina on pitäjän, kaupungin tai maakunnan nimi ja pääsana ilmaisee aina puhujan sukupuolen: 
Elimäen likka, Tammelan emäntä, Tornion akka; Laukaan poika, Ahlaisten ukko, Savon ukko, Sortavalan mies.

Kolmantena ja harvinaisimpana paikkaan viittaavana ilmauksena on murteen nimitys. Tällöin käytetään luontevimmin kokonaista heimomurretta. Läheskään kaikilla suomen murteilla ei ole kuitenkaan sopivaa maakuntaan tai heimoon perustuvaa kansanomaista nimitystä, ja matkimuksissa esiintyvätkin tällaisina vain savo ja pohjalainen. Ilmauksilla puhua savvoo ja puhua pohojalaasta tai pohojalaista jäljitellään nykyäänkin pohjoissavolaista ja eteläpohjalaista murretta (ks. lukua 4.5).

Matkimuksiin sisältyy myös selviä pitäjänmurteiden nimityksiä. Nämä vastaavat muodoltaan savoa ja pohjalaista: niissä on siis pitäjännimen perusmuoto tai lAinen-johdos.

Tiijäks miten kemiksi leiliä peshän? Käänethän nurin ja nuolashan. (Vokaalienvälisen h:n säilymä ja $h$ :n etisen vokaalin kato; Ojansuu 1908: 10.)

Moksi sinä sotkamoksi, minä moksin paltamoksi (moksia puhumisesta, tehokeinona riimi; Leino 1968: 17).

ne sitä "laakaalaista", sitä "laakaalaista" siellä [puhuivat] - - ainakin kaiv vanhemmat ihmiset puhuvat "laakaata" vielä (diftonginreduktio; Jyväskylä, eläkeikäinen nainen; NPM 1979).

Kankaanpiäläinen [= Kankaanpään murre] se on niin mahlotointa (diftongiutuminen ja t:n astevaihtelu; Paulaharju 1908: 124).

Kemi, paltamo ja sotkamo kuuluvat kaikki ilmaustyyppiin puhua sanoa $x: k s i$ 'x:n murteella'. Ilmauksissa laakaa ja kankaanpiäläinen jäljitelty piirre kuuluu itse nimiin. Laukaan murteen diftonginreduktiota $a u>$ aa jäjitellään useissa repliikkimatkimuksissa, joten laakaasta tai laakaalaisesta on helppo puhua yleisemminkin. Kankaanpää kuuluu hämäläismurteiden yläsatakuntalaiseen moo, pee -alueeseen (Kankoonpee), mutta tämä mua, piä -diftongiutumisen vaikutus on Pohjanmaalta merkityssä matkimuksessa muistettu virheellisesti. $t: n$ astevaihteluvarianttina on kuitenkin hämäläismurteisiin kuuluva $l$.

Viime vuosien murrebuumissa on pyritty nostamaan murteiden statusta, ja murteella kirjoitetuissa teosten ja sanakirjojen nimissä käytetään toisinaan kieli-termiä, esimerkiksi Raamatun parhaat paikat Rauman giälell; Kalevala savon kielellä; Tavvoo savvoo: savon kielen sanakirja. Kieli-sanan käyttö tällaisissa yhteyksissä, siis murteen asemesta, ei ole kuitenkaan uusi ilmiö, kuten esimerkiksi Suomen murteiden sanakirjan fraseologia osoittaa (SMS s.v. kieli, 2.III). Myös matkimuksissa termi esiintyy: Lopuist koott ikä ['kuin'] Laitlan kiäl kuvaa lounaismurteisiin kuuluvan murteen lyhyyttä (Leino 1968: 139).

\section{$4 \quad$ Paikanilmauksia sisältävät matkimustyypit}

\subsection{Kielenkäyttäjä sanoo}

Wellerismit, jotka on kansanrunoudentutkimuksessa suomennettu joskus sanomuksiksi (Järviö-Nieminen 1959: 13), ovat yksi vanhojen murrematkimusten 
suosittu formula. Wellerismien rakenteena on repliikki + johtolause sanoi $X+$ mahdollinen jatke.

Kei kun hei, sano perniöläine (Punttila 1998: 19).

Seun nietua se, sano karjalainen kaupoissa (jatkeena kaupoissa; Punttila 1998: 57).

Tilurimpsistä, sano Tornion akka, kun juna läks (jatkeena kun-lause; Punttila 1998: 43).

Järviö-Nieminen (1959), joka on tutkinut suomalaisia sanomuksia, nimittää ensimmäisen esimerkin mukaista rakennetta $y k s i n k e r t a i s e k s i$ ja jatkeen sisältävää rakennettakehitellyksi wellerismiksi. Sananparsityyppi on hänen mukaansa tullut Suomeen lännestä ruotsalaisten välittämänä, todennäköisesti jo 1600luvulla. Se on vähitellen levinnyt myös Itä-Suomeen, ja leviämissuunta näkyy sen yleisyydessä: eräiden laskelmien mukaan wellerismien osuus kaikista sananparsista on länsimurteiden alueella selvästi suurempi (12 \%) kuin itämurteiden alueella $(4 \%)$. Wellerismien sanojat Järviö-Nieminen on jakanut aineistonsa perusteella useaan ryhmään. Ihmisten lisäksi sanojina voivat olla mielikuvitukselliset puhujat, kuten piru tai eläimet. Ihmisryhmistä erottuvat kansallisuudet, paikkakuntien asukkaat, eri alojen ammattilaiset ja nimeltä mainitut henkilöt. Myös sukupuoli on monissa wellerismityypeissä olennainen; miehet ovat naisia useammin repliikkien sanojina. (Järviö-Nieminen 1959: 23, 48-49, 83-84, 95-97.)

Murrematkimusten wellerismit kuuluvat alaryhmään, jossa sanojan sosiaalisena yhteisönä on heimo tai paikkakunta. Koska päähuomio on repliikin murteellisuudessa, niissä riittää usein yksinkertainen formula; ne eivät siis välttämättä tarvitse jatketta kuten silloin, kun tilannekomiikka syntyy repliikin ja jatkeen välisestä ristiriidasta (ks. Järviö-Nieminen 1959: 56-57). Muista matkimustyypeistä murteenpilkkawellerismit eroavat siinä, että niissä on aina mainittu puhujan alueellinen tausta. Heimoista tulevat kysymykseen lähinnä sellaiset, jotka tunnistetaan selvimmin murteen puolesta: hämäläiset, pohjalaiset, savolaiset ja karjalaiset. Näistä voidaan vielä joskus erottaa sukupuoli, vaikka sillä ei ole samanlaista asemaa sukupuoliroolien osoittamisessa kuin muissa wellerismeissä (vrt. Östman 2002: 84): hämäläismies, pohjalaiseukko, Savon ukko.

Itte vaan, sano hämäläinen (ts-yhtymän vastine $t$; Nirvi \& Hakulinen 2004: 372).

Juot tievettä, sitä ne herrattii juovat, sano Savon ukko kun hevostaan rapakosta juotti (tee- ja tie-sanojen homonymia; huom. tilannetta selittävä jatke; Nirvi \& Hakulinen 2004: 376).

Ulkopuolelle jäävät tässä käyttämäni aineiston mukaan mm. varsinaissuomalaiset eli lounaismurteiden puhujat, satakuntalaiset ja uusmaalaiset. Näiden murteita ei pystytä identifioimaan maakunnan perusteella. Lounaismurteisiin viitataan nykyään jonkin keskeisen kaupungin mukaan, ja Satakunta ja Uusimaa eivät taas muodosta yhtenäisiä murreryhmiä, vaan jakautuvat kahden murreryhmän - hämäläismurteiden ja lounaisten siirtymämurteiden - alueelle.

Yleisempiä ovatkin sellaiset wellerismit, joissa johtolauseessa mainitaan tietyn paikkakunnan edustaja. Hänestä käytetään joko neutraalia lAinen- 
johdosta tai sukupuolen ilmaisevaa tyyppiä X:n likka, X:n mies. Poikkeuksellinen on johtolausetyyppi Hollolan palokunta, joka esiintyy l-matkimuksissa. Hollolanlahlen murre ja hämäläinen $l$ ovat tulleet tunnetuiksi jo 1700-luvulla laajemmaltikin, kun hollolalaiset ovat tehneet markkinamatkoja Satakuntaan ja Varsinais-Suomeen. (Leino 1968: 60, 79-80.) Muista paikkakunnista ovat wellerismeissä olleet suosittuja Lammi, Iitti ja Laihia (Järviö-Nieminen 1959: 100).

Mitäs kel on kun pil soi, sano raumalainen, kun juna vihelsi (loppuheitto; Punttila 1998: 17).

Velä, velä, sano tammelainen härkää ( $t$ : l; Punttila 2001: 25).

Sekhan joukhon, sanoo härmäläänen (h:n säilymä; Punttila 2001: 27).

Menthiin, sano kittiläläinen, vaikka yksin meni (h:n säilymä; Punttila 2001: 29).

Jääks nääks yäks? kysyi Tampereen tyttö (nääks-partikkeli ja ä:n toistuminen; Punttila 1998: 29).

En tielä ny, saa nählä ny, sano Lammin likka ( $t$ : l; Punttila 2001: 25).

Voi yhren kerran, sano Vehkalahren miäs ( $t$ : r; Punttila 1998: 27).

Okko mun, okko, tukko meille, tukko? sanoo Jurvan poika kauhajokiselle flikalle (verbien pikapuhemuodot ja $t k>k k$; Punttila 2001: 27).

Joko lähletään, sano Hollolan palokunta ( $t$ : l; Punttila 1998: 25).

Murrematkimuksissa näkyy hyvin alussa mainittu Länsi- ja Itä-Suomen ero: wellerismejä on selvästi enemmän länsimurteiden alueelta. Itämurteiden puolelta samanlaisia formuloita on aineistossani vähän. Itä-Suomen harva asutus on ollut yksi este lännestä tulleen sanaparsityypin yleistymiselle (JärviöNieminen 1959: 50-51).

Syöp ja lyöp, sano kuopiolainen (pi-tunnuksinen preesens; Järviö-Nieminen 1959: 196).

Kasso sie vaa isse isseis, kyl mie isse issei kasso! sano Antrea mies humalas (ts-yhtymän vastine ss; Punttila 1998: 55).

Wellerismien keskeisenä funktiona on toiseuden osoittaminen, joten ne viittaavat yleensä oman ryhmän ulkopuolelle. Erilainen murre ilmentää hyvin tätä toiseutta, ja kielenkäyttö ja puhetapa ovat laajemminkin - esimerkiksi eri kielten kesken - yksi suosittu wellerismien aihe. (Ks. Östman 2002: 84-86.) Wellerismien sanojat ovat vaihdelleet eri aikoina. 1880-luvun ja 1930-luvun sananparsiaineiston perusteella paikkakuntalaiswellerismien käyttö on vähentynyt hiukan ja tilalle on tullut enemmän sanomuksia, joissa mainitaan jonkin ammatin harjoittaja (esim. suutari, vrt. myös palokunta). Yhteiskunnalliset ja sosiaaliset syyt ovat siis vaikuttaneet tämän sananparsityypin käyttöön; liikenne ja tiedonvälitys ovat tasoittaneet paikkakuntien välisiä eroja ja vähentäneet kiusoittelun tarvetta. (Järviö-Nieminen 1959: 100-102.) Viime vuosina virinnyt murteiden harrastus on kuitenkin elvyttänyt matkimusten ja kielikaskujen kerrontaa, ja uusiin kokoelmiin sisältyy selvästi vanhoihin formuloihin puettuja 
sanaleikkejä, kuten Tästä ei enää pilot parane, kehui hämäläismies lentäjää; Ei kyllä naarata, sanoi savolaispoika, kun anoppi hukkui (Punttila 1998: 25, 48). Edellisessä on mukailtu hämäläisittäin sanontaa tästä eivät pidot parane (hämäläismurteissa pilot, vrt. pilotti), jälkimmäinen perustuu naurattaa- ja naarata-verbien homonymiamuotoihin.

\subsection{Kielenkäyttäjä toimii}

Murteenpuhujiin viitataan wellerismien lisäksi monissa toteavissa matkimuksissa, joissa matkija kertoo ulkopuolisena havainnoijana ironisoivasti näiden tekemisistä. Kielenkäyttäjä mainitaan joko yksikössä tai monikossa, ja jäljitelty murrevariantti kuuluu verbimuotoon. Ilmaus on siis formuloitu muotoon paikkakuntalainen tekee tai paikkakuntalaiset tekevät. Tällaisia toteamuksia näyttää olevan esimerkiksi yleisgeminaatiosta ja t:n astevaihtelusta, jotka molemmat voivat aiheuttaa homonymiaa:

Ähtäriläinen tappaa hyvän ystävänsä kirkossakin (tavata- ja tappaa-verbien homonymia; Leino 1968: 153).

Virtolaisekkin ovat taas hierottaneet maantiensä (hiedoittaa- 'hiekoittaa' ja hierottaaverbien homonymia; Leino 1968: 73).

Hollolanlahtelainen paaluttaa sylämmensä (paaduttaa- ja paaluttaa-verbien homonymia; Punttila 1998: 25).

Joitakin toteamuksia tehostaa verbimuodon tai muiden samankaltaisten ääänneasujen toisto, ja muodoissa voi olla useitakin piirteitä yhdessä:

Pöytyäläinen puhhuu ja sannoo, lihhaa ja kallaa, mennee ja tullee, makkaa ja hallaa (yleisgeminaatio, tehokeinona riimi; Leino 1968: 152).

Ensin porilainen karraa [karata : karaa 'juosta'], sitte se lankee kurraan, sitte se piru vielä porraa ['parkuu'] (yleisgeminaation lisäksi r:n ääntämys; Ojansuu 1908: 11).

Sellasii o uuskirkkoset, ensi kipuvelloot ja kapuvelloot, sit putovelloot ja sit viel kirovelloot [= kipuilevat, kapuilevat, putoilevat, kiroilevat] (e-loppuisen vokaaliyhtymän säilymä, t-päätteinen persoonamuoto ja yleisgeminaatio; Punttila 2001: 36).

Aina ei jäljitelty murremuoto ole näissä toteamuksissa verbissä, vaan sen määritteissä. Verbimuoto voi tällöin olla jopa murteenvastainen, kuten seuraavissa esimerkeissä:

Tamperelainen mänee [p. o. menee tai mennee] mairolle ( $t: r$; Leino 1968: 74).

Luumäkeläiset mäneet [p. o. mänööt] raannan ['kiulun'] kans heruttammaa ['lypsämään'] lehmiä (sanasto; Punttila 1998: 57).

Kielenkäyttäjien toimintaa kuvaavissa matkimuksissa on myös eri murteiden vertailuja. Murre-erot ilmaistaan erilaisilla äänne- ja muotovarianteilla, ja repliikki voi olla neutraali toteamus tai homonymialeikittely: 
Kirvulaine ajjaa hevosesa kirkkomääl passaal, kaukolaine pahtaal [= patsaalle] (ts-yhtymän vastineet ss ja $h t$; Leino 1968: 156).

Virtailainen pyytää kaloja kurusta, keuruulainen pyytää kaloja kuusta, ruovesiläinen pyytää kaloja kulusta (kutu-sanan heikkoasteisten muotojen homonymia sanojen kuru, kuu ja kulku kanssa; Leino 1968: 35).

Vertailu on yksi ei-kielitieteilijöiden keino arvioida murteiden keskinäisiä suhteita. Samankaltaisuutta ja erilaisuutta kuvataan usein sanallisesti ilman kielenainesesimerkkejä, mutta matkimuksissa rinnastetaan erilaiset variantit ja osoitetaan kyseiset murteet kielenkäyttäjään tai paikkakuntaan viittaavilla paikanilmauksilla. (Ks. Mielikäinen 2005: 108-110.)

\subsection{Murrepiirteet matkimusten kielenainesesimerkkeinä}

Matkimusten merkitys on siinä, ettei niissä tarvita varsinaista metakieltä. Ne paljastavat suoraan jäljitellyn murteen piirteitä, ja saman äänneasun mahdollinen toisto varmistaa sen, mistä piirteistä on kyse. Niinpä niissä on hyvin vähän varsinaisia metakielisiä termejä, ja nämäkin ovat yleistajuisia ja laajoja käsitteitä, kuten sana tai kieli (ks. lukua 3), esimerkiksi Kolome kovvoo Savonmuan sannoo: pölökky, pilikku ja polliisi (yleisgeminaatio ja svaavokaali; Punttila 1998: 50). Silti sekä vanhoihin että uusiin matkimuksiin kuuluu myös ilmauksia, joissa nostetaan tietoisemmin esiin vain jäljitelty kielenpiirre, äänne- tai muotovariantti ja joskus jopa ilmiö. Yksinkertaisimmillaan tämä jäljittely on nominilausekkeen muodossa Paikkakunnan a tai paikkakuntalaisen $a$, jossa $a$ on murrevariantti, kuten persoonapronomineihin kohdistuvissa matkimuksissa Kokemäen mää ja sää ja Rovaniemen miet-siet (persoonapronominit; Leino 1968: 199, 164). Persoonapronominit ovat erityisen helposti tunnistettavia murrepiirteitä (ks. lukua 4.4), joten niitä voidaan jäljitellä eri tavoin. Ne leimaavat kielenkäyttäjiä jopa sosiaalisesti, kuten seuraavassa matkimuksessa, jossa huomautetaan kaupungissa käyneelle alatorniolaiselle hienostelusta: Onko se Kukkuki Oulussa käyny ko "minnää" puhhuu. Alatorniolla persoonapronominivariantti on peräpohjalaiseen tapaan mie, ja matkimusta on käytetty, jos joku on muutellut puhettaan. (Nirvi \& Hakulinen 2004: 376.)

Yleisempää näyttää aineistoni perusteella olevan eri murteiden vertailu esimerkiksi edellä mainitun lausekeformulan toistolla, siis luettelemalla paikkakuntien murrevariantteja:

Härmän että, Kauhavan jotta, Lapuan notta, Kuurtanehen nokiotta (konjunktiot; Ojansuu 1908: 12).

Kesälahen "kuuma" ja Parikkalan "palava" (kuuma-sanan vastineet; Leino 1968: 15).

Ensimmäinen esimerkki osoittaa, että partikkelit kiinnittävät pronominien tapaan huomiota, jos ne poikkeavat omasta kielenkäytöstä. Kontrastia lisää niissä se, että kyse on puheessa usein toistuvista, muuten lähes huomaamattomista pikku sanoista. (Mielikäinen 2005: 104.) Että-konjunktiolla alkavasta partikkeliluettelosta on useita eteläpohjalaisia toisintoja, ja konjunktioiden jatkeena voi olla muitakin sanoja (joo, niin, jukolauta). 
Murrevariantteja on vertailtu myös puhujan näkökulmasta esitetyillä repliikeillä; näissä mainitaan sanaston ja äänneasujen lisäksi irrallisia äänteitä:

Ennen minä Pälkäneen ärrää pärrään ennenkö luopioislaisten ällää lällään (t:n astevaihtelu; Leino 1968: 70).

Ennen minä Luopioisten ällää lällään ku pälkäneläisten ärrää pärrään (t:n astevaihtelu; Leino 1968: 70).

Kaustislaisten törkiä ei oo niin paljo ku Ullavan mahjoton (törkiän 'erittäin, hyvin', astevaihtelu $h t$ : hj; Leino 1968: 75).

t:n astevaihtelu on ollut suomalaisten useimmin jäljittelemä murreilmiö (Leino 1968: 202). Varsinkin länsimurteiden ärrästä ja ällästä on tehty monentyyppisiä matkimuksia. Edellä mainituista repliikeistä on samanlaisia toisintoja monista hämäläispitäjistä, ja niissä vertaillaan mm. Orimattilan, Vehkalahden tai Virtain ärrää Ruoveden, Nastolan, Sippolan tai Iitin ällään. Kolmannen esimerkin törkiä ja mahjoton edustavat äänteellisesti eri kielenpiirteitä, mutta sanoja voidaan käyttää osin synonyymisesti (esim. törkiän mahjottoman hyvä; Leino 1968: 75).

Murteiden jäljittelyyn samoin kuin murrekaskuihin sisältyy usein sanaleikkejä, ja edellä on tullut jo esimerkkejä homonymian käytöstä. Seuraavissa matkimuksissa esitetään paikallinen murrepiirre humoristisesti ja kuvallisesti predikatiivilauseella:

'Vai nii' o luvialaisten pelto (vainii = vainio, io-yhtymän assimilaatio ja homonymia; Nirvi \& Hakulinen 2004: 380).

Hythet, luthet ja mathet [= hyteet 'hyttyset', luteet ja mateet] ovat kälvhiläisten [kälviäläisten] suolakaloja (h:n säilymä; Ojansuu 1908: 10).

Kielenilmiöitä määrittelevä metakieli ei ole viimeksi mainituissa esimerkeissä enää kovin selvä, ja myös raja edellisen luvun (Kielenkäyttäjä toimii) esimerkkeihin on häilyvä. Näiden kahden ryhmän rajamaastoon jääkin monenlaisia repliikkejä, joissa murrepiirre nousee selvemmin esiin kielenaineksena tai sulautuu itse matkimuksessa ilmaistun väitteen tai toteamuksen osaksi.

\subsection{Kielenkäyttäjän kotipaikka}

Koska murrematkimukset kuuluvat vanhaan suomalaiseen sananparsiperinteeseen, niiden käyttö on alkanut tyrehtyä. Yhteiskunnalliset syyt ovat myös vaikuttaneet siihen, että naapurimurteiden sijasta voidaan jäljitellä kaukaisempiakin murteita. Pitkiä, vakiintuneita sanontoja näistä jäljittelyistä syntyy harvemmin. Nykyajan matkimuksissa on vähän sellaisia repliikkejä, toteamuksia tai kysymyksiä, jotka täyttävät tarkat matkimuksen kriteerit. Monet niistä ovat lentäviä lauseita, kuten Onko Mikkeliin mänijöitä, juna läks justiinsa, tai tervehdyksiä ja muita kiinteitä fraaseja, esimerkiksi kui sää, notta terve, voe hyvänen aeka. (Mielikäinen 2005: 102-103.)

Nykynuorten tuntemiin matkimuksiin kuuluu yksi selvä sananparsimatkimus: Ookko nää Oulusta? Se voi saada peräänsä useita erilaisia kysymyksiä, 
kuten juokko nää piimää, pelekääkkö nää polliisia, vai ookko nää muuten pölijä ym. Tämän matkimuksen Leino (1968: 206-208) on ajoittanut 1960-luvulle, ja hänen mukaansa se edustaa muutenkin uutta kansanperinnettä siinä, että toisin kuin vanhat sananparret se tunnetaan laajalla alueella nimenomaan nuorten keskuudessa. Siitä on saatu runsaasti esimerkkejä viime vuosien asennetutkimuksissa, ja se on lähes ainoita nuorten tuntemia sananparsimatkimuksia. Esimerkiksi vuonna 2004 teettämässäni kyselyssä (JY 2004), jossa opiskelijoiden täytyi esittää haastattelijalle valmiiksi nimettyjen murteiden tärkein tuntomerkki, lähes puolet vastaajista mainitsi kysymyksen Ookko nää (Oulusta) Oulun murteen tuntomerkkinä. Tosin useimmat vastaukset (22) olivat muodossa ookko nää, mutta tämä johtunee ainakin osin siitä, että Oulun murre mainittiin jo kysymyksessä. (Mielikäinen 2005: 101; ks. myös Palander 2005: 82.)

Edellä mainittu kysely paljasti myös, että nuorilla on muitakin repliikkimatkimuksia, joissa varioidaan kotipaikan ilmaisevaa formulaa joko toteamuksena tai kysymyksenä: Minä olen X:stä Oletko sinä X:stä? Laajalle levinnyt Ookko nää Oulusta -kysymys on jopa saattanut antaa mallin tähän formulaan. Kyselyn kohteina oli 8 eri murretta ja Helsingin slangi, ja kaikkiaan neljästä muodostettiin tällaisia paikannimen sisältäviä ilmauksia esimerkkeinä ensiksi mieleen tulevasta murrepiirteestä:

Oon Turuust; Joo mä oon Turuust; Oot sä Turuust?

Mää oon Tampereelt.

Siis just mä oon Stadist (lisämainintana "hesalainen s").

Mie oon Lappeenrannast.

Samaan formulaan viittaavat vastauksissa myös muutamat elliptisiksi ilmauksiksi tulkittavat elatiivimuodot, kuten Turuust, Tampereelta nääs TampeRReelta ( $r: n$ ääntämys), Pohojanmaalta. Kotipaikkaformula on helppokäyttöinen, ja täydellisissä lauseissa se paljastaa yleensä myös persoonapronominin murreasun. Yksikön 1. ja 2. persoonalla on kaikissa suomen murteissa käytössä jokin yleiskielestä poikkeava pikapuhemuoto (mie, miä, mää, mä, mnää), jota käytetään ainakin jossain muodossa. Persoonapronominit tunnistetaan myös helposti, joten niiden perustella pystytään erottelemaan eri murteiden puhujia. Murteiden tasoittumisesta huolimatta vielä nykyäänkin ovat tunnettuja $\mathrm{mm}$. peräpohjalaisten ja karjalaisten mie, sie -asut, ja helsinkiläiset leimautuvat herkästi lyhytvokaalisen $m \ddot{a}, s \ddot{a}$-variantin perusteella. (Esim. Niedzielski \& Preston 2000: 10-11; Mielikäinen \& Palander 2002: 98; Mantila 2004: 332-333; Mielikäinen 2005: 104-105.)

Kotipaikkaformulaa voi siis pitää tyypillisenä nykymatkimuksena. Se ei silti ole tuntematon vanhoissa matkimuksissakaan. Seuraavissa esimerkeissä jäljitellään yksikön 1. tai 2. persoonan pronominivariantin lisäksi muitakin murrepiirteitä, kuten a:n ja ä:n loppuheittoa, diftonginreduktiota, diftongiutumista ja yleisgeminaatiota. Ilmauksia tehostavat samanlaisten äänneasujen tai äännerakenteiden toistot sekä alku- tai sisäsointu. 
Mää olen omast Vihrist mää (Leino 1968: 165).

Minnoon kaakaa, oon Laakaasta (Leino 1968: 121).

Uot sie ukko Uuveltkirkolt. - Uonha mie, mut uot sie? (Leino 1968: 169.)

Meä o Lemi etiält, suure kive takoa (Leino 1968: 107).

Mie oon Kitteem pittäästä kattaapehkosta verrään korvasta (Kettunen 1930: 126).

Vihti kuuluu lounaisiin siirtymämurteisiin (Länsi-Uusimaa). Laukaa (KeskiSuomi) ja Kitee (Pohjois-Karjala) edustavat savolaismurteita, Uusikirkko ja Lemi kaakkoismurteita. Samoista matkimuksista on myös toisintoja, joista persoonamuoto puuttuu kokonaan. Esimerkiksi lemiläisiä ja kiteeläisiä voidaan jäljitellä pelkällä paikanmääritteiden luettelolla.

Matkimustyyppi Minä olen X:stä on suuremman sananparsiryhmän alalaji, sillä formulasta on runsaasti myös sellaista aineistoa, jossa ei jäljitellä murretta. Sen sijaan näissä toteamus- tai kysymysmuotoisissa - joskus myös passiivilla ilmaistuissa - sananparsissa joko kehutaan itseä tai kiusoitellaan naapuria viittaamalla kotipaikkaan. Aina ei paikkakuntaa tai sen asukasta ole mainittu, mutta murteesta voi päätellä, mistäpäin sananparsi on. Sananparsikokoelmien (Nirvi \& Hakulinen 2004) perusteella tätä tyyppiä on runsaasti Länsi-Suomesta, varsinkin Etelä-Pohjanmaalta.

Minä oonkin sieltä mihinä on punaanen tupa, tuulimylly ja seittemän lehemää (Ilmajoki; Nirvi \& Hakulinen 2004: 363).

Härmästä ollahan, sanoo Perääspoika ku sängyn alta luuras (Nirvi \& Hakulinen 2004: 382).

Narraa mua, moon Nurmoosta! (Nirvi \& Hakulinen 2004: 382.)

Ookko hullu vai Kyrööstä? (Nirvi \& Hakulinen 2004: 382.)

Oulusta oon ja kehtaan sanua (Nirvi \& Hakulinen 2004: 378).

Kyllä piru oot jos Porist oot, mut koko perkele jos Kokemäeltä! (Nirvi \& Hakulinen 2004: 380.)

Yksi tämän tyypin sananparsista viittaa erityisesti paikkakunnan köyhyyteen, alun perin nälkävuosien kerjäläisiin: Kankoonpeestä Jumala nähköön misä halla panee airan seipeekki (Punttila 1998: 30). Siitä on toisintoja eri pitäjistä, kuten Ullavasta Jumala parakkoon, missä - -; Nurmoosta Jumala nähköhön - - johona - (Leino 1968: 87-88).

Kotipaikan ilmaukset Minä olen X:stä, X:stä ollaan tai Oletko sinä X:stä ovat aiemmin olleet vahvasti latautuneita ilmauksia, sillä kuten edellisistä esimerkeistä voi päätellä, niihin on usein sisältynyt kehua, uhoa, ironiaa tai uhkaa. Myös uudempi sananparsimatkimus Ookko nää Oulusta ilmaisee asenteita, kuten näkyy sen jatkeista, esimerkiksi kysymyksestä vai ookko nää muuten pölijä. Muut nykynuorten keksimät kotipaikkarepliikit (Mä oon Stadist jne.) vaikuttavat neutraaleilta, mutta niiden käyttö perustunee alun perin tietyssä sävyssä 
lausuttuihin kiusoitteluihin. Murteesta kiusoittelun pelko on ollut vielä viime vuosikymmeninäkin todellista, kuten käy ilmi seuraavasta esimerkistä, joka on peräisin 1970-luvulta, eteläpohjalaisen nuoren haastattelusta:

Miksei se siälä [muualla Suomessa] oop paha jos jotkut ihimiset vihaa siälä pohojalaasia ni, (ei) se oikee hianoa [ole] jos joku tuloo ja, humauttaa nyrkillä pian että, "mitäs sä oop Pohojammaalta" (Lapua, lukiolaispoika; NPM 1979).

\subsection{Murreasuinen paikanilmaus}

Aiemmin esiteltyjen wellerismien johtolauseet voivat myös jäljitellä murretta. Jos paikanilmauksessa esiintyy tällöin jokin kyseisen murteen variantti, se vahvistaa matkimuksen humoristista tai ironisoivaa luonnetta, koska se kohdistuu suoraan kielenkäyttäjään: (sano) laitlalainen 'laitilalainen' (lounaismurteinen sisäheitto), orimattilain 'orimattilalainen' (kaakkoishämäläinen in-loppuinen inen-nomini), Ruovelen likka (hämäläinen l), ilimajokelaanen (eteläpohjalainen svaavokaali ja $i$-diftongin monoftongiutuminen).

Helposti jäljiteltäviä paikanilmauksia ovat sellaiset kuntien ja kaupunkien nimet, jotka sisältävät jo perusmuodossaan jonkin paikallisen murteen piirteen, esimerkiksi

$$
\begin{aligned}
& \text { Kittee }=\text { Kitee, } \text { Kajjaani }=\text { Kajaani (yleisgeminaatio) } \\
& \text { Pettäävesi }=\text { Petäjävesi (j:n kato ja yleisgeminaatio) } \\
& \text { Nurmoo }=\text { Nurmo }(<\text { Nurmoi; } i \text {-diftongin monoftongiutuminen }) \\
& \text { Ilamajoki } \text { Ilimajoki = Ilmajoki, Halasua }=\text { Halsua (svaavokaali) } \\
& \text { Ikoolinen = Ikaalinen, Kankoonpee }=\text { Kankaanpää, Vieksy }=\text { Vääksy, Joakkima }=\text { Jaakki- } \\
& \text { ma (aa:n ja ä̈̈:n vastineet) } \\
& \text { Laaka }=\text { Laukaa (diftonginreduktio). }
\end{aligned}
$$

Nimissä Kankoonpee ja Laakaa jäljittelyn tehoa vahvistaa toisto: edellisessä on sekä aa:n että ää:n murteellinen vastine, jälkimmäiseen on diftonginreduktion vuoksi tullut kaksi aa:ta. Vanhoille sananparsimatkimuksille on tyypillistä, että niissä on toistettu samankaltaisia sanoja ja sananmuotoja, niin että näistä syntyy alku-, sisä- tai loppusointu. Tällaisia esimerkkejä on monista edellä luetelluista paikannimistä:

Ilimajoelta tuuloo niin vilipoosta (svaavokaali; Leino 1968: 144).

Vieks tie tie Vieksyyn (ä̈̈:n diftongiutuminen; Leino 1968: 99).

Mennään Pettääveille verräitä kahtoon (aja, äjä -nominien savolaiset vastineet; Leino 1968: 160).

Tuleppas Laakaaseen niin paakaatan [= paukautan] taaluus ['kasvoihisi'] (au-diftongin reduktio; Punttila 1998: 48). 
Vaikka paikannimen perusmuodossa ei olisi murteen kannalta mitään erikoista, taivutusmuodoissa on mahdollista jäljitellä moniakin äänne- ja muotopiirteitä. Ilmiö tuli esiin jo kotipaikkaformuloissa (Turuust, Lappeenrannast), mutta siitä on runsaasti myös muita sananparsimatkimuksia. Seuraavissa esimerkeissä jäljitellään sijapäätteiden tai taivutusvartalon äänneasuja:

Äl men Turkku, siäl panna puukko kurkku (geminaatio; Punttila 1998: 18)

Vorsasa maakunnassa kovasa kännisä (yksinäis-s:llinen inessiivi; Leino 1968: 163).

Ei misseen puhuta niin selevee suamee kun Kyröh, Karkuh, Kankoonpeeh ja Ikaalihih (tavunloppuisen s:n muuttuminen $h$ :ksi; Punttila 1998: 32).

Oon Kyröhnä enkä Kiimingihnä, sanoi kyröläinen, kun Kiimingin nimismiestä naamaan tälläsi (eteläpohjalainen inessiivin pääte - $h n A$; Punttila 1998: 36).

Menhän venhellä Kemhin (h:n säilymä; Punttila 1998: 43).

Jäljitellyn murrepiirteen toisto on saanut toisinaan aikaan hyperdialektalismeja, siis liioitteluja, jotka eivät kuulu todelliseen murteeseen. Edellisistä esimerkeistä tällainen on inessiivimuoto Ikaalihih < Ikaalisis 'Ikaalisissa', jossa vokaalienvälinen $s$ :kin on muutettu $h$ :ksi, vaikka muutos koskee vain tavun- ja sananloppuista s:ää. Kajaanin geminoituneesta asusta on vanha sanonta Kajjjaanista kolomen jiin kanssa (Leino 1968: 153). Hyperdialektaalisia ovat seuraavienkin matkimusten paikanilmaukset:

Skaustislaisten skäki se skukkuu (sananalkuinen sk-yhtymä omaperäisissä sanoissa; Leino 1968: 150).

Seissemänsataa seissemänkymmentä seissemän on kaussislaisen vuosiluku (ts-yhtymän vastine ss myös asukkaannimessä kaustislainen; Punttila 1998: 40)

Sattiit tulloo, vuattiit kastuu, assiit vuatii Kuopiis käymää (ee:n ja ia, iä -yhtymän vastine ii myös nimessä Kuopio 1; Punttila 1998: 52).

Myös nykynuoret tuntevat fraaseja ja sanontoja, joissa paikannimen murreasulla on keskeinen asema. Osa näistä on vanhempaa muistitietoa, osassa muistellaan mainoksia ja muita lentäviä lauseita, ja mukaan mahtuu myös murteenvastaisia äänneasuja: Oulusa koulusa, tois pual jokke [joki = Aurajoki Turussa], Luostholle [Luostolle] lysthin pittoon. Itsekin näitä ilmauksia pystytään muokkaamaan: Laphin se on menthävä. (Palander 2005: 79, 83; Mielikäinen 2005: 103.) Mainituista repliikeistä Luostholle ja menthävä sisältävät ylimääräisen $h: n$, ja tällainen liioittelu on tyypillistä peräpohjalaisia murteita jäljiteltäessä.

Kun murteita jäljitellään nykyään sananparsien sijasta lyhyemmillä fraaseilla ja irrallisilla sananmuodoilla, paikannimien murreasut ovat helppo tapa viitata kyseiseen murteeseen. Maakunnista, heimoista ja heimomurteista ovat eri-ikäisille suomalaisille yhä tuttuja Pohojanmaa, pohojalaiset $\sim$ pohojalaaset ja pohojalaanen [murre], joilla viitataan yleensä Etelä-Pohjanmaahan (esim. Palander 2005: 80-81; Mielikäinen 2005: 105-106). Svaavokaali herättää huo-

$1 \quad$ Lauri Kettusen mukaan (1960: 140) Pohjois-Karjalassa tavattaisiin myös asua Kuopija. Näin ollen taivutusmuotokin voisi olla ii:llinen. 
miota erityisesti, jos se eroaa oman murteen svaasta (Leino 1968: 148); esimerkiksi savolaismurteissa tunnetaan svaa vain l-alkuisissa konsonanttiyhtymissä ja nh-yhtymässä.

[Murre-eroista] Pohojanmaa: sanoonnat ovat vähä niinko pohojanmaan pellot (Jyväskylä, turkulainen naisopiskelija; Arve 2002: 48).

Ja sitten, no, "pohojalaista" murretta hyvin harvon kuulee, täällä - - (Jyväskylä, Viitasaarelta muuttanut keski-ikäinen mies, NPM 1979).

Keski- ja pohjoispohjalaiset, joiden murteissa svaa kuuluu eteläpohjalaisten murteiden tapaan myös $h$-alkuisiin konsonanttiyhtymiin, erottavat sen sijaan eteläpohjalaiset nimeltä ja tunnistavat murre-eroksi $i$-diftongin oikenemisen:

pitkää eteläpohojalaasta [murretta] (Keski-Pohjanmaa, Veteli; Björckbacka 2002: 38).

Vrt. Keskipohojanmaan murretta puhun tietennii (Jyväskylä, keskipohjalainen miesopiskelija; Arve 2002: 15).

Pohjanmaahan rinnastuva ilmaus on savo, jonka partitiivimuodolla savvoo viitataan murteen puhumiseen: (puhua vääntää) savvoo. Savolaismurteiden länsilaidalla sillä on myös keskisuomalainen variantti savvoa. Olennainen ilmiö molemmissa varianteissa on yleisgeminaatio, joka laajasta levikistään huolimatta mainitaan usein (Pohjois-)Savon murteen keskeisenä tuntomerkkinä (JY 2004).

Savon tunnistaa kahdennuksesta "puhhuu savvoo" - - (Jyväskylä, pohjoissavolainen naisopiskelija; Arve 2002: 48).

kyllä se oli toisellaista se puhe iha, kyllä oikeestaan suoraan sanoen niin savova, "savvoo" se oli (Jyväskylä, eläkeikäinen mies; NPM 1979).

no "savvoaha" o-, "savvoaha ossoa" kaikki (Jyväskylä, Karstulasta muuttanut keskiikäinen mies; NPM 1979).

savvoo kovvoo ja hiljoo (JY 2004).

Nykymatkimuksissa on erityisen paljon Turku-nimestä muodostettuja hyperdialektalismeja. Taivutusmuotoja jäljitellään $\mathrm{mm}$. pidentämällä toisen tavun vokaalia: Jos Suomen Turuuskik käy ni - - (Keski-Pohjanmaa, Haapajärvi, keskiikäinen nainen; Leipälä 2000: 72). Puheessa lopputulos ei tällöin vastaa aitoa intonaatiota, sillä vierasmurteinen ei osaa ääntää sananmuotoon kuuluvaa "kiekausta" (Wiik 1998: 45). Turku-nimeen liitetään jäljittelyissä myös murteenvastainen illatiivin pääte -sse: Turkkusse pro Turkku. Taivutusmuodoista on abstrahoitu taas uusia taivutusmuotoja, kuten Turuuhun, Turgusees, Turkuseen ym. Nämä osoittavat, että lounaismurteita on vaikea jäljitellä - kuten yleensä murteita, joissa on paljon vieraita piirteitä (Mielikäinen 2005: 102, 105; ks. myös lukua 4.6). 


\subsection{Vanhat ja uudet köllinimet}

Yksi vanhojen matkimusten alalaji on köllinimet. Suomessa on erittäin runsas kölliperinne, ja useimpien pitäjien asukkaille on annettu kiusoittelumielessä nimityksiä, jotka perustuvat hyvin erilaisiin seikkoihin. Nimeämisperusteisiin kuuluu myös murre, ja näin ovat syntyneet esimerkiksi Jämsän ylypiit komiit ja Korplahe koriit, joissa pilkan kohteena on asukkaiden luonteen lisäksi PäijätHämeen länsiosien murteisiin kuuluva $e A$-yhtymän ii:llinen vastine. Köllinimissä Slaihian skitrut 'Laihian itarat' ja Skyrön skälmit 'Kyrön kelmit' on taas paikannimiinkin saatu hyperdialektaalinen s-alkuinen konsonanttiyhtymä. (Mänty 1962: 141, 144; Leino 1968: 110, 150.)

Murretta on käytetty eri pitäjäläisten köllinimissä laajemminkin kuin edelliset esimerkit antavat ymmärtää. Paikkakunta tai sen asukkaat on nimetty uudestaan leikillisellä primaarinimellä, joka perustuu johonkin matkijalle outoon tai usein toistuvaan murresanaan. Esimerkiksi eteläpohjalaisia Kauhajoen asukkaita on nimitetty jottanmaalaisiksi $(<$ jotta), pohjoissavolaisia Keiteleen asukkaita pottupittään pojiksi (< pottu 'peruna') ja pohjoiskarjalaisia Ilomantsin Tyrjän kyläläisiä retentyrjäläisiksi (< reten 'hyvin, sangen'). (Mänty 1962: 144-147; Leino 1968: 14-15.)

Vaikka nykyään ei enää ole muodissa aivan samanlainen köllinimien käyttö kuin aikaisemmin, naapureita saatetaan kiusoitella samaan tapaan uusien epävirallisten paikannimien avulla. Varsinkin nuoret ovat antaneet Suomen kaupungeille ja kunnille, joskus myös suuremmille alueille, epävirallisia käyttö- tai lempinimiä (Saarinen 2004). Osa niistä on tavallisia slangijohdoksia, siis tyypillisiä sekundaarinimiä, kuten Riihis 'Riihimäki', mutta joukossa on myös leikillisiä primaarinimiä. Kummassakin nimityypissä on yhä mahdollista käyttää paikallista murretta, niin että nimet ovat samalla murrematkimuksia. Nykynuoret nimittävät Etelä-Pohjanmaata erikoisen inessiivityypin mukaan Mihnämihnämaaksi, ja eteläpohjalaiset ovat mihnämihnämaalaisia (Mielikäinen 2005: 103). Missään muussa suomen murteessa ei tunneta inessiivin päätettä $h n A$, jossa tavunloppuinen $s$ on muuttunut $s n A$-vaiheessa soinnillisen konsonantin edellä $h$ :ksi. Nimitys on osuva siitäkin syystä, että $h n A$-pääte kuuluu vain omistusliitteisiin muotoihin ja pronominimuotoihin: tosihnansa; mih(i)nä, kuh(u)na, ei mih(i)nään. Näistä varsinkin jälkimmäiset on helppo erottaa eteläpohjalaisen puheesta. Mih(i)nämaa Mih(i)näkuh(u)namaa mainitaan myös sotilasslangissa (Penttinen 1984 s.v. Mih(i)nämaa) .

Nykyajan epävirallisiin nimiin kuuluu Turkua tarkoittava Turkkune (Saarinen 2004: 6). Se on abstrahoitu murteenvastaisesti jäljitellystä sseillatiivista Turkkusse (oikea muoto Turkku), ja analogiamallina ovat olleet inennominit, vrt. ihmine : ihmisse. Samankaltainen abstrahoituma on Kuopijjo 'Kuopio' (Saarinen mp.), joka perustuu geminoituneeseen illatiivimuotoon Kuopijjoo. Siirtymä-äänteiden $j$ ja $v$ geminaatio on savolaismurteissa erikoisgeminaatiota laajalevikkisempi ja vahvempi - siis selvemmin erottuva -ilmiö (Mielikäinen 1981: 205-207; Palander 1987: 61-63, 67-69). Jyväskylässä vieraspaikkakuntalaisia samoin kuin ulkomaalaisia ihmetyttää murteeseen kuuluva toisen tavun 
vokaalin pidentäminen, ja niinpä liioitellusta äänneasusta on tehty kölliä muistuttava epävirallinen nimi:

Kyllä originaalit JYVÄÄÄSKYÄLÄISET huomaa (Jyväskylä, eteläsavolainen miesopiskelija; Arve 2002: 48).

- - vokaalien venytys: "Jyvääskyläässä"! (Jyväskylä, hämäläinen naisopiskelija; Arve 2002: 62).

Jyväskylän nimi on erityisen otollinen lyhyen ensi tavun jälkeisen lyhyen vokaalin pitenemiselle, jonka Wiik (1985: 273-274, 295-306) on todennut kuuluvan lounaismurteiden ja peräpohjalaisten Tornion murteiden lisäksi myös suomen itämurteisiin. Wiikin mittausten mukaan Jyväskylästä pohjoiseen on alue, jolla piteneminen on vahvempaa kuin muissa itämurteissa. Ilmiön huomaavat varsinkin hämäläismurteiden alueella asuvat, kun taas paikkakuntalaiset eivät itse kiinnitä siihen samalla tavalla huomiota.

Nykyajan murteelliset paikannimet muistuttavat köllinimiä siinä, että niillä osoitetaan usein asenteita. Murre saattaa implikoida mm. paikkakunnan pienuutta ja syrjäisyyttä suurempien paikkakuntien näkökulmasta tai muita vastaavia ominaisuuksia: "Nurmoo, Kuartanes ja Ylistaroo [= Nurmo, Kuortane ja Ylistaro] ovat murreliioitteluja, sopii varsinkin Nurmoohon" (Jyväskylä, lapualainen miesopiskelija; Saarinen 2004: 6). Myös suurempaa ja mahtavampaa voidaan pilkata pejoroivilla murreväännöksillä. Helsingille on muualla Suomessa annettu savolaismurteita mukailevat nimet Helesinki ja Piäkaapunki, ja sen slangivastinetta Hesa saatetaan taivuttaa maalaismaisesti geminoituneessa asussa (mennä) Hessaan (Saarinen mp.). Savolaismurteissa ei alkuaan ole ollut svaata ls-yhtymässä, mutta eräissä vanhoissa murretutkimuksissa mainitaan poikkeukseksi kirosanana käytetty Helesinki (esim. Etelä-Savo, Tarkiainen 1904: 25; Pohjois-Karjala, Reijonen 1893: 10). Slangissa syntynyt Hesa ei Paunosen mukaan (2000 s.v. Hesa) ole enää paljasjalkaisten stadilaisten käytössä, vaan kuuluu enemmän ulkopaikkakuntalaisten suuhun.

\section{Päätäntö}

Olen edellä nostanut esiin murteiden jäljittelyjä, joissa eksplikoidaan kyseinen murre jollakin paikkaan viittaavalla ilmauksella. Ryhmät eivät ole mitenkään tarkkarajaisia, eivätkä ne aina edes erotu selvästi toisistaan. On myös selvää, että niiden ulkopuolelle jää paljon formulaltaan vaihtelevia sananparsimatkimuksia, joihin kuuluu paikanilmaus. Vahvin, lähes pakollinen asema paikanilmauksilla on wellerismeissä ja murrepiirteiden - äänne- ja muotovarianttien sekä murresanojen - vertailussa. Sen sijaan kotipaikan ilmaiseva formula Minä olen X:stä ei ole aina tarvinnut paikakseen selvästi nimettyä pitäjää tai maakuntaa, vaan siitä on vanhoissa sanaparsissa muunkintyyppistä aineistoa (- - sieltä 
mihinä on - -). Nykymatkimuksissa paikkakunta on kuitenkin kotipaikkaformulan olennainen osa.

Eri aikoina syntyneitä paikanilmauksia voisi kokoavasti tarkastella useasta näkökulmasta. Vanhoissa matkimuksissa näkyvät samat erot kuin sananparsissa yleensä: esimerkiksi wellerismit ovat tyypillisempiä länsisuomalaisille kuin itäsuomalaisille. Nykyään tällaisilla eroilla ei ole suurta merkitystä, sillä 1700-1800-luvulta nykypäivään on tapahtunut suuri muutos sekä maantieteellisesti että yhteiskunnallisesti. Entisajan suomalaiset kiinnittivät huomiota lähimpien naapureittensa puheenparteen tai omassa murteessa esiintyvään vaihteluun, joskin heillä oli esimerkiksi kauppa- ja markkinamatkoilla mahdollisuus tutustua kaukaisempiinkin murteisiin. Alueelliset seikat ohjasivat näin ollen jäljittelyä, ja matkimuksia syntyi erityisesti varianttien levikkirajoilla. Kielenpiirteiden havaitsemisesta tiedetään, että mitä vähemmän kahden murteen välillä on eroja, sitä helpommin ne huomataan. Esimerkiksi svaavokaalista muovatut matkimukset ovat lähes kaikki svaa-alueelta. Ilmiö on tunnistettu varsinkin silloin, kun svaan äänneympäristö tai laatu on poikennut oman murteen svaasta, kuten tyypeissä lehemä, nelejä, tylysä, ilama ja ilema, kylömä. (Leino 1968: 148.) Nykyään murrevarianttien levikkirajoilla ei ole tällaista merkitystä, kun murteet ovat tasoittuneet ja sekoittuneet, eivätkä rajanaapuritkaan ole enää samanlaisessa erityisasemassa kuin ennen.

Paikannimien asema on nykyisessä murteiden jäljittelyssä vahva myös nimistöntutkimuksen näkökulmasta. Nimiä muistetaan vanhoista sananparsimatkimuksista (Laakaa, laakaalainen) ja lentävistä lauseista (Onko Mikkeliin mänijöitä?), niitä omaksutaan mediasta (Luostholle...) ja niiden avulla muokataan myös uusia repliikkejä tai fraaseja (Laphin se on menthävä). Pitäjien ja kaupunkien nimistä on tullut osin köllinimiin verrattavia lempi- tai pilkkanimiä, ja murreasuisia nimiä voidaan käyttää epävirallisina niminä (Kuartanes). Kummassakin tapauksessa niillä osoitetaan asenteita kielenkäyttäjiä ja heidän kotipaikkaansa kohtaan. Toisaalta nimillä voidaan korostaa myös omaa asemaa. Tässä suhteessa kiinnostava ilmiö on sekä vanhoista sananparsista että nykymatkimuksista tunnettu formula Minä olen X:stä, jolla joko kehutaan omaa tai pilkataan toisen kotipaikkaa.

Lopuksi paikanilmaukset tarjoavat kielitieteellisesti kiintoisan tutkimuskohteen sekä murteentutkijalle että kansanlingvistille. Tiettyyn formulaan vakiintuneissa vanhoissa sananparsimatkimuksissa nimet jäävät toisinaan murteen ulkopuolelle vain neutraaleiksi paikanilmauksiksi, mutta jos niistä voidaan muodostaa jokin naapurimurteelle tyypillinen äänneasu, tämä vahvistaa matkimuksen tehoa. Helposti jäljiteltäviä murreasuja ovat olleet perusmuodossaan esimerkiksi Kankoonpee (Kankaanpää) ja Laakaa (Laukaa), murteellisia taivutusmuotoja taas Vorsasa (Forssassa), Kyröh (Kyrössä) ja Turkku (Turkuun). Monet savolaistyyliset vokaalien muutokset, esimerkiksi pitkän a:n ja ä:n diftongiutuminen, eivät kuitenkaan ole puhekielessä enää kovin hyvin säilyneitä piirteitä, joten matkimuksen kohteeksi nousevat muut ilmiöt. Nykyään korostuvatkin erityisesti keston muutokset ja vaihtelut, joita on sekä paikanilmausten vokaaleissa että konsonanteissa: Nurmoo, Jyvääskylä, Oulusa koulusa, savvoo. Helposti tunnistettavia ovat myös sellaiset murrepiirteet, joissa on 
kokonaisen äänteen ero yleiskieleen tai omaan puhekieleen. Tällaisia vaihteluja aiheuttavat svaavokaali (Pohojanmaa, Helesinki) ja h:n säilymä. Kun murteita ja niiden ilmiöitä ei tunneta lähemmin, syntyy helposti myös liioiteltuja, murteenvastaisia hyperdialektalismeja ( Turkkusse, Luostholle).

Paikannimillä ja niihin perustuvilla murteen- tai asukkaannimillä näyttää nykymatkimuksissa olevan keskeinen asema. Omakohtaista kosketusta aluemurteisiin ei välttämättä edes tarvita, eikä paikkojen tarvitse olla tuttuja. Liikenne, tiedonvälitys ja opetus ovat tuoneet Suomen paikkakunnat ja kaupungit toisella tavalla jokaisen ulottuville, ja radion ja television lisäksi myös kirjoitettu kieli - mm. 1990-luvulta lähtien julkaistu murrekirjallisuus ja sähköinen media - luo ja levittää uudenlaista matkimusperinnettä. Murteelliset äänne- ja muotoasut jäävät helposti mieleen, kun ne liittyvät paikanilmauksiin. Nämä ilmaukset toimivat siten eräänlaisina murteiden nimilappuina, jotka auttavat myös tunnistamaan ja muistamaan vaihtelevien varianttien alueellisia taustoja. 


\section{LÄHTEET}

Andersson, L.-G. 2001 [1985]. Fult språk. Svordomar, dialekter och annat ont. Femtonde tryckningen. Stockholm: Carlssons bokförlag.

Arve, L. 2002. Murtaen, sortaen vai juuret irti repien? Katsaus Jyväskylän yliopisto-opiskelijoiden murreasenteisiin. Pro gradu -tutkielma. Julkaisematon. Jyväskylän yliopiston kielten laitos, Fennicum.

Björckbacka, R. 2002. Veteliläisten käsityksiä murteesta. "Rinta rottingille ja murthet rohkiasti eshin!" Pro gradu -tutkielma. Julkaisematon. Jyväskylän yliopiston kielten laitos, Fennicum.

Deprez, K. \& Persoons, Y. 1987. Attitude. Teoksessa Ammon, U., Dittmar, N.\& Mattheier, K. J. (toim.) Sociolinguistics I. An International Handbook of the Science of Language and Society. Berlin - New York: Walter de Gruyter, 125-132.

JY 2004 = Suomen kielen alueellisen vaihtelun kurssilla (syksy 2004) tehty kysely murrepiirteistä. Vastaajina 102 ammattikorkeakoulun ja yliopiston opiskelijaa. Jyväskylän yliopiston kielten laitos, Fennicum.

Järviö-Nieminen, I. 1959. Suomalaiset sanomukset. Suomalaisen Kirjallisuuden Seuran toimituksia 259. Helsinki: SKS.

Kettunen, L. 1930. Suomen murteet II. Murrealueet. Suomalaisen Kirjallisuuden Seuran toimituksia 188. Helsinki: SKS.

Kettunen, L. 1940. Suomen murteet III. A. Murrekartasto. Suomalaisen Kirjallisuuden Seuran toimituksia 188. Helsinki: SKS.

Kettunen, L. 1960. Matkapakinoita ja muita muistelmia 1925-1960. Helsinki: Kirjavälitys Oy.

Kuusi, M. 1954. Sananlaskut ja puheenparret. Helsinki: SKS.

Leino, P. 1968. Suomalaiset matkimukset. Pro gradu -tutkielma. Julkaisematon. Helsingin yliopiston suomen kielen laitos.

Leipälä, S. 2000. Haapajärvisten murreasenteista. Pro gradu -tutkielma. Julkaisematon. Jyväskylän yliopiston kielten laitos, Fennicum.

Mantila, Harri 2004. Murre ja identiteetti. Virittäjä 108, 322-346.

Mielikäinen, A. 1981. Etelä-Savon murteiden äännehistoria I. Konsonantit. Suomalaisen Kirjallisuuden Seuran toimituksia 375. Helsinki: SKS.

Mielikäinen, A. 2005. Matkimuksista määritelmiin. Miten murteista puhutaan. Sananjalka 47. Suomen Kielen Seuran vuosikirja, 98-118.

Mielikäinen, A. \& Palander, M. 2002. Suomalaisten murreasenteista. Sananjalka 44. Suomen Kielen Seuran vuosikirja, 86-109.

Mänty, Kirsti 1962. Suomalaiset vieraspaikkakuntalaisten köllinimet. Pro gradu -tutkielma. Julkaisematon. Helsingin yliopiston suomen kielen laitos.

Niedzielski, N. A. \& Preston, D. 2000. Folk Linguistics. Trends in Linguistics. Studies and Monographs 122. Berlin - New York: Mouton de Gruyter. 
Nirvi, R. E. \& Hakulinen, L. (toim.) 2004. Suomen kansan sananparsikirja. Kuudes painos. Näköispainos kuvattu kirjan 1953 ilmestyneestä toisesta painoksesta. Sanakirjasäätiön toimituksia V. Helsinki: WSOY.

NPM 1979 = Nykysuomalaisen puhekielen murros. Jyväskyläläisten ja eteläpohjalaisten haastattelujen litteraatiot 1976-1979. Jyväskylän yliopiston kielten laitos, Fennicum.

Ojansuu, H. 1908. Kansa murrehavaintojen tekijänä. Virittäjä 12, 9-13.

Palander, M. 1987. Suomen itämurteiden erikoisgeminaatio. Suomalaisen Kirjallisuuden Seuran toimituksia 455. Helsinki: SKS.

Palander, M. 2005. Muu suomi karjalaisten silmin. Teoksessa M. Palander \& Nupponen, A.-M. (toim.) Monenlaiset karjalaiset. Suomen karjalaisten kielellinen identiteetti. Studia Carelica Humanistica 20. Joensuu: Joensuun yliopisto, 56-90.

Paulaharju, S. 1908. Yhtä ja toista. Kansa murrehavaintojen tekijänä. Virittäjä 12, 124.

Paunonen, H. 2000. Tsennaaks Stadii, bonjaaks slangii. Stadin slangin suursanakirja. Laatineet Heikki ja Marjatta Paunonen. Helsinki: WSOY.

Penttinen, A. 1984. Sotilasslangin sanakirja. Porvoo-Helsinki-Juva: WSOY.

Preston, D. 1996. Whaddayaknow?: The Modes of Folk Linguistic Awareness. Language Awareness. Vol. 5:1, 40-74.

Punttila, M. 1998. Haaskannäköinen tyttö. Kielikaskuista matkimuksiin. Porvoo-Helsinki-Juva: WSOY.

Punttila, M. 2001. Pilkettä silmäkulumaan. Kielikaskuista sanaleikkeihin. Helsinki: WSOY.

Reijonen, E. 1893. Nurmeksen murteesta. Äänne- ja muoto-opillinen tutkimuskoe. Suomi III:6. Helsinki: SKS.

Saarinen, J. 2005. Tsadista Rolloon. Suomen paikkakuntien epävirallisia nimiä. Proseminaariesitelmä. Julkaisematon. Jyväskylän yliopiston kielten laitos, Fennicum.

SMS = Suomen murteiden sanakirja. Seitsemäs osa. Kotimaisten kielten tutkimuskeskuksen julkaisuja 36. Helsinki 2003.

Tarkiainen, V. 1904. Äännehistoriallinen tutkimus Juvan murteesta. Suomi IV:2. Helsinki: SKS.

Wiik, K. 1985. Suomen murteiden vokaalien kestoista. Teoksessa Aaltonen, O. \& Hulkko, T. (toim.) Fonetiikan päivät - Turku 1985. XIII Fonetiikan päivillä Turun yliopistossa 30. - 31.8.1985 pidetyt esitelmät. Turun yliopiston suomalaisen ja yleisen kielitieteen laitoksen julkaisuja 26. Turku: Turun yliopisto, 253-317.

Wiik, K. 1998. Tämmöttös. Turun murteen kielioppi ja harjoituskirja. 2. painos. Turku.

Östman, J.-O. 2002: Sulvan kansan wellerismit konstruktiona. Teoksessa Herlin, I., Kalliokoski, J., Kotilainen, L. \& Onikki-Rantajääskö, T. (toim.), Äidinkielen merkitykset. Suomalaisen Kirjallisuuden Seuran toimituksia 869. Helsinki: SKS. 